Bull. Chem. Soc. Ethiop. 2007, 21(1), 63-73.

ISSN 1011-3924

Printed in Ethiopia

(c) 2007 Chemical Society of Ethiopia

\title{
SYNTHESIS AND CHARACTERIZATION OF TRANSITION METAL COMPLEXES DERIVED FROM SOME BIOLOGICALLY ACTIVE FUROIC ACID HYDRAZONES
}

\author{
P. Venkateswar Rao*, K. Ashwini and S. Ammani \\ Department of Chemistry, P. G. College of Science (O. U.), Hyderabad - 500 004, India
}

(Received December 13, 2005; April 28, 2006)

\begin{abstract}
Two new physiologically active ligands, N'-2-[(E)-1-hydroxy-4-methyl-2-oxo-2H-8-chromenyl) ethylidene)-2-furan carbohydrazide (HMCFCH) and N'-2-[(Z)-1-(4-hydroxy-6-methyl-2-oxo-2H-pyranyl) ethylidene]-furan carbohydrazide (HMPFCH) and their VO(II), $\mathrm{Mn}$ (II), $\mathrm{Fe}$ (II), $\mathrm{Co}$ (II), Ni(II) and $\mathrm{Cu}$ (II) complexes have been prepared. The ligands and the metal complexes have been characterized by elemental analyses, electrical conductance, magnetic susceptibility measurements, UV-Vis, IR, and ESR spectroscopic data. Basing on the above data, $\mathrm{Fe}$ (II) and $\mathrm{Co}$ (II) complexes of $\mathrm{HMCFCH}$ and $\mathrm{HMPFCH}$ have been assigned a dimeric octahedral geometry. VO(II) complexes of $\mathrm{HMCFCH}$ and $\mathrm{HMPFCH}$ have been assigned sulfate bridged dimeric square pyramidal geometry. Mn(II) complex of $\mathrm{HMCFCH}$ has been assigned a dimeric octahedral geometry, where as $\mathrm{Mn}$ (II) complex of $\mathrm{HMPFCH}$ has been ascribed to monomeric octahedral geometry. $\mathrm{Cu}$ (II) and $\mathrm{Ni}$ (II) complexes of HMCFCH have been ascribed to a polymeric structure. Ni(II) complex of HMPFCH has been assigned a dimeric square planar geometry. $\mathrm{Cu}$ (II) complex of $\mathrm{HMPFCH}$ has been proposed an octahedral geometry. The ligands and their metal chelates were screened against $S$. aureus and $P$. aeruginosa. The ligands and the metal complexes have been found to be active against these microorganisms. The ligands show more activity than the metal complexes.
\end{abstract}

KEY WORDS: N'-2-(E)-1-hydroxy-4-methyl-2-oxo-2H-8-chromenyl) ethylidene)-2-furan carbohydrazide (HMCFCH), N'-2-[(Z)-1-(4-hydroxy-6-methyl-2-oxo-2H-pyranyl) ethylidene]-furan carbohydrazide (HMPFCH), 3-Acetyl-6-methyl-2H-pyran-2,4(3H)-dione, 8-Acetyl-4-methyl-Umbelliferone, Furoic acid hydrazide, Anti microbial activity

\section{INTRODUCTION}

Furoic acid hydrazones and their metal complexes are of recent interest [1-6]. Hydrazones and their metal complexes show varied applications in the fields such as anti fungal, anti bacterial, anti oxidative and cytotoxic studies [7-10]. They have been found to be potential chemo therapautic agents $[11,12]$. 3-Acetyl-6-methyl-2H-pyran-2, 4(3H)-dione and 8-acetyl-4-methylumbelliferone and furoic acid hydrazide together form Schiff bases which are potential chelating agents and exhibit good physiological and biological activities [13, 14]. In Continuation to our recent studies [15], it has been proposed to synthesize and characterize the transition metal complexes derived from some hydrazones.

\section{EXPERIMENTAL}

3-Acetyl-6-methyl-2H-pyran-2,4(3H)-dione and furoic acid hydrazide are Fluka reagents. They were used as such. 8-Acetyl-4-methyl umbelliferone was synthesized as reported earlier [16, 17]. Metal salts and other reagents used in the investigation were of AnalaR grade. The solvents used were purified before use. Melting points or decomposition temperatures were determined with Bock-Monoscop-Werck-NR instrument. UV-Vis spectra were recorded on a UV-Vis-Near IR Varian Cary 5E instrument. IR spectra ( $\mathrm{KBr}$ discs) were recorded on Bruker IFS-66V FT-IR spectrophotometer. ${ }^{1} \mathrm{H}$ NMR spectra were recorded on NMR Jeol-GSX-400 MHz spectrometer. Electrical conductivities of the metal complexes were studied at room temperature with freshly

*Corresponding author. E-mail: pallapothulav@yahoo.com 
prepared $1 \mathrm{mM}$ solutions in DMSO using Systronics model No: 304 conductivity meter. ESR spectra were recorded as powder on a Varian EPR-E-112 spectrometer. TG and DT analyses were recorded on NETZSCH TGA-DTA/DSC instrument. Metal estimations were carried out using a Varian Spectra AA-20 plus atomic absorption spectrometer. The magnetic susceptibility measurements were carried out by Guoy method at room temperature using $\left[\mathrm{Hg}\left(\mathrm{Co}(\mathrm{SCN})_{4}\right]\right.$ as a calibrant. Carbon, hydrogen and nitrogen were determined by microanalyses at CDRI, Lucknow, India.

Preparation of the ligand $\mathrm{HMCFCH}$. The ligand $\mathrm{HMCFCH}$ was prepared by mixing 4-methyl8 -acetyl umbelliferone $(0.218 \mathrm{~g}, 1 \mathrm{mmole})$ in $20 \mathrm{~mL}$ methanol with furoic acid hydrazide $(0.126$ $\mathrm{g}, 1 \mathrm{mmole}$ ) in $20 \mathrm{~mL}$ methanol in a 1:1 proportion. The two solutions were heated under reflux for $4 \mathrm{~h}$. After cooling over night, a yellowish crystalline compound separated out. It was recrystallized from methanol. Yield $(49.6 \%)$, m.p. $250{ }^{\circ} \mathrm{C}$.

Preparation of the ligandHMPFCH. The ligand $\mathrm{HMPFCH}$ was prepared by mixing 3-acetyl-6methyl-2H-pyran-2,4(3H) dione $(0.168 \mathrm{~g}, 1 \mathrm{mmole})$ in $20 \mathrm{~mL}$ methanol with furoic acid hydrazide $(0.126 \mathrm{~g}, 1 \mathrm{mmole})$ in $20 \mathrm{~mL}$ methanol in a 1:1 proportion and the two solutions were heated under reflux for $4 \mathrm{~h}$. After cooling overnight, a yellowish crystalline compound separated out. It was recrystallized from methanol. Yield (48.5\%), m.p. $217^{\circ} \mathrm{C}$.

Preparation of the complexes of HMCFCH. In the preparation of $\mathrm{Mn}(\mathrm{II}), \mathrm{Co}(\mathrm{II}), \mathrm{Ni}$ (II) and $\mathrm{Cu}$ (II) complexes, the respective metal chlorides $(1 \mathrm{mmole})$ in $10 \mathrm{~mL}$ of methanol were heated under reflux with 2 mmoles of $\mathrm{HMCFCH}(0.652 \mathrm{~g})$ in $15 \mathrm{~mL}$ of methanol. The mixture was heated under reflux for $4 \mathrm{~h}$. The $\mathrm{pH}$ of the reaction was adjusted to 8 using aqueous ammonia solution and the solution was further heated under reflux for two more hours. The metal chelates were separated out upon cooling over night. In the preparation of $\mathrm{Fe}(\mathrm{II})$ and VO(II) complexes, ferrous ammonium sulfate and vanadyl sulfate were used. The metal salts were dissolved in aqueous methanol medium. The ligand and the metal salts were taken in the ratio of 2:1 and they were heated under reflux for $4 \mathrm{~h}$. Upon over night cooling the solutions, the metal chelates separated out. The metal complexes separated out were filtered through the sintered glass crucible and were successively washed with water, methanol and pet ether $\left(60-80{ }^{\circ} \mathrm{C}\right)$ and they were dried in vacuum.

Preparation of the complexes of HMPFCH. In the preparation of $\mathrm{Mn}(\mathrm{II}), \mathrm{Co}(\mathrm{II}), \mathrm{Ni}(\mathrm{II})$ and $\mathrm{Cu}$ (II) complexes the respective metal chlorides $(1 \mathrm{mmole})$ in $10 \mathrm{~mL}$ of methanol were heated under reflux with 2 mmoles of $(0.552 \mathrm{~g}) \mathrm{HMPFCH}$ in $15 \mathrm{~mL}$ of methanol for around $4 \mathrm{~h}$. The $\mathrm{pH}$ of the reaction solution was adjusted to 8 using aqueous ammonia solution and the solution was further heated under reflux for two more hours. The metal complexes were separated out upon cooling. In the synthesis of $\mathrm{Fe}$ (II) and VO(II) complexes ferrous ammonium sulfate and vanadyl sulfate were used, respectively and the metal salts were dissolved in aqueous methanol medium. The ligands and metal salts were taken in 2:1 ratio and they were heated under reflux for $4 \mathrm{~h}$. Upon cooling the solutions overnight, the metal chelates were separated out. The metal chelates thus isolated were filtered through the sintered glass crucible. They were successively washed with aqueous methanol and pet-ether $\left(60-80{ }^{\circ} \mathrm{C}\right)$ and dried in vacuum.

\section{RESULTS AND DISCUSSION}

The analytical data of the ligands and their metal complexes are given in Table 1 and it is in good agreement with the proposed structures and geometries of the ligands and complexes, 
respectively. All the metal complexes (Table 2) are colored, stable to air at room temperature and are non-hygroscopic. They decompose without melting above $300{ }^{\circ} \mathrm{C}$. The complexes are insoluble in water, methanol, and acetone and are fairly soluble in dimethyl formamide and dimethyl sulfoxide. All the metal chelates show residual conductance values $\left(10-29 \Omega^{-1} \mathrm{~cm}^{2}\right.$ $\mathrm{mol}^{-1}$ ) in $1 \times 10^{-3} \mathrm{M}$ DMF solution, indicating that they are non-electrolytes (Table 2).

Table 1. Analytical data of the complexes and ligands.

\begin{tabular}{|l|c|c|c|c|c|}
\hline \multirow{2}{*}{ Ligand/complex } & \multicolumn{5}{|c|}{ Found (calcd) \% } \\
\cline { 2 - 6 } & Metal & Carbon & Hydrogen & Nitrogen & Sulfur \\
\hline $\mathrm{HMCFCH}\left(\mathrm{C}_{17} \mathrm{H}_{14} \mathrm{O}_{5} \mathrm{~N}_{2}\right)$ & - & $62.57(61.66)$ & $4.29(4.59)$ & $8.58(9.04)$ & - \\
\hline$\left[\right.$ VOHMCFCH ${ }_{2} \mathrm{SO}_{4}$ & $11.74(11.61)$ & $46.52(46.48)$ & $2.78(2.73)$ & $6.42(6.38)$ & $3.71(3.65)$ \\
\hline$\left[\mathrm{MnHMCFCH} .2 \mathrm{H}_{2} \mathrm{O}\right]_{2}$ & $13.32(13.24)$ & $49.24(49.16)$ & $3.89(3.86)$ & $6.81(6.75)$ & - \\
\hline$\left[\mathrm{FeHMCFCH} .2 \mathrm{H}_{2} \mathrm{O}\right]_{2}$ & $13.52(13.43)$ & $49.12(49.06)$ & $3.92(3.85)$ & $6.79(6.73)$ & - \\
\hline$\left[\mathrm{CoHMCFCH} .2 \mathrm{H}_{2} \mathrm{O}\right]_{2}$ & $14.16(14.07)$ & $48.83(48.70)$ & $3.87(3.82)$ & $6.71(6.68)$ & - \\
\hline$[\mathrm{NiHMCFCH}]_{n}$ & $15.40(15.34)$ & $53.42(53.31)$ & $3.21(3.14)$ & $7.43(7.32)$ & - \\
\hline$\left[\mathrm{CuHMCFCH} . \mathrm{H}_{2} \mathrm{O}_{2} \mathrm{Cl}\right]$ & $14.43(14.41)$ & $46.31(46.26)$ & $3.22(3.17)$ & $6.37(6.35)$ & - \\
\hline $\mathrm{HMPFCH}\left(\mathrm{C}_{13} \mathrm{H}_{12} \mathrm{O}_{5} \mathrm{~N}_{2}\right)$ & - & $56.52(56.21)$ & $4.34(4.12)$ & $10.14(10.71)$ & - \\
\hline$[\mathrm{VOHMPFCH}]_{2} \mathrm{SO}_{4}$ & $12.57(12.49)$ & $38.31(38.24)$ & $3.24(3.19)$ & $6.95(6.88)$ & $3.98(3.92)$ \\
\hline$[\mathrm{MnHMPFCH}]_{2}$ & $9.16(9.08)$ & $51.67(51.58)$ & $3.71(3.64)$ & $9.38(9.26)$ & - \\
\hline$\left[\mathrm{FeHMPFCH} .2 \mathrm{H}_{2} \mathrm{O}\right]_{2}$ & $15.29(15.22)$ & $42.64(42.53)$ & $4.17(4.09)$ & $7.71(7.63)$ & - \\
\hline$\left[\mathrm{CoHMPFCH} .2 \mathrm{H}_{2} \mathrm{O}_{2}\right.$ & $15.56(15.47)$ & $42.47(42.40)$ & $4.17(4.08)$ & $7.69(7.61)$ & - \\
\hline$[\mathrm{NiHMPFCH}]_{2}$ & $17.69(17.64)$ & $46.98(46.89)$ & $3.13(3.01)$ & $8.54(8.42)$ & - \\
\hline$[\mathrm{CuHMPFCH}]_{2}$ & $10.39(10.35)$ & $50.96(50.85)$ & $3.66(3.59)$ & $9.24(9.13)$ & - \\
\hline
\end{tabular}

Table 2. Physical characteristics and conductivity data of metal complexes and ligands.

\begin{tabular}{|l|l|c|c|c|}
\hline Ligand/complex & \multicolumn{1}{|c|}{ Color } & $\begin{array}{c}\text { Melting/decomposition } \\
\text { temperature, }{ }^{0} \mathrm{C}\end{array}$ & Yield $(\%)$ & $\Lambda_{\mathrm{m}}\left(\Omega^{-1} \mathrm{~cm}^{2} \mathrm{~mol}^{-1}\right)$ \\
\hline $\mathrm{HMCFCH}$ & Light yellow & 250 & 49.6 & - \\
\hline$[\mathrm{VOHMCFCH}]_{2} \mathrm{SO}_{4}$ & Light green & $>350$ & 51.5 & 21.4 \\
\hline$\left[\mathrm{MnHMCFCH} .2 \mathrm{H}_{2} \mathrm{O}\right]_{2}$ & Light brown & $>360$ & 52.0 & 20.8 \\
\hline$\left[\mathrm{FeHMCFCH} .2 \mathrm{H}_{2} \mathrm{O}\right]_{2}$ & Red & $>350$ & 51.5 & 22.3 \\
\hline$\left[\mathrm{CoHMCFCH} .2 \mathrm{H}_{2} \mathrm{O}\right]_{2}$ & Red & $>360$ & 48.0 & 27.3 \\
\hline$[\mathrm{NiHMCFCH}]_{n}$ & Pinkish red & $>350$ & 52.0 & 28.3 \\
\hline $\left.\mathrm{CuHMCFCH.H} \mathrm{O}_{2} \mathrm{O} . \mathrm{Cl}\right]$ & Yellowish green & $>350$ & 59.0 & 16.7 \\
\hline $\mathrm{HMPFCH}$ & Light yellow & $>217$ & 48.5 & - \\
\hline$[\mathrm{VOHMPFCH}]_{2} \mathrm{SO}_{4}$ & Yellow brown & $>340$ & 61.0 & 15.3 \\
\hline$[\mathrm{MnHMPFCH}]_{2}$ & Light brown & $>350$ & 52.5 & 14.8 \\
\hline$\left[\mathrm{FeHMPFCH} .2 \mathrm{H}_{2} \mathrm{O}\right]_{2}$ & Red & $>360$ & 56.0 & 14.2 \\
\hline$\left[\mathrm{CoHMPFCH} .2 \mathrm{H}_{2} \mathrm{O}\right]_{2}$ & Red & $>360$ & 45.0 & 13.7 \\
\hline$[\mathrm{NiHMPFCH}]_{2}$ & Pinkish red & $>360$ & 46.0 & 10.8 \\
\hline$[\mathrm{CuHMPFCH}]_{2}$ & Yellowish green & $>360$ & 58.0 & 15.1 \\
\hline
\end{tabular}

The IR spectra of HMCFCH and HMPFCH exhibit characteristic bands at 3500-3400, 1720$1700,1670-1660,1640-1620$ and $1470-1310 \mathrm{~cm}^{-1}$ which are ascribed to $\mathrm{vOH}$ (hydrogen bonded), $v \mathrm{C}=\mathrm{O}$ (azide), $\mathrm{vC}=\mathrm{N}$ (azomethine) and $\mathrm{vC}=\mathrm{O}$ (phenolic), respectively. The infrared frequency at $1080 \mathrm{~cm}^{-1}$ in both the ligands is due to $\mathrm{vC}-\mathrm{O}-\mathrm{C}$ of the furan ring [18]. 
<smiles>C/C(=N/NC(=O)c1ccco1)c1c(O)ccc2c(C)cc(=O)oc12</smiles>

$\mathrm{HMCFCH}$

The ${ }^{1} \mathrm{H}$ NMR spectrum of $\mathrm{HMPFCH}$ exhibits the following signals in $\mathrm{CDCl}_{3}: \delta 2.18(\mathrm{~s}, 3 \mathrm{H}$, $\left.\mathrm{C}_{6}-\mathrm{CH}_{3}\right), 2.6\left(\mathrm{~s}, 3 \mathrm{H}, \mathrm{CH}_{3}-\mathrm{C}=\mathrm{N}\right), 5.78\left(\mathrm{~s}, 1 \mathrm{H}, \mathrm{C}_{5}-\mathrm{H}\right), 8.2(\mathrm{~s}, 1 \mathrm{H}, \mathrm{CONH}), 6.6(\mathrm{~m}, 1 \mathrm{H}, \mathrm{H}-2$ furoyl), 7.3 (m, 1H, H-3 furoyl), 7.7 (m, 1H, H-4 furoyl) and $11.57(\mathrm{~b}, 1 \mathrm{H}, \mathrm{OH})$.

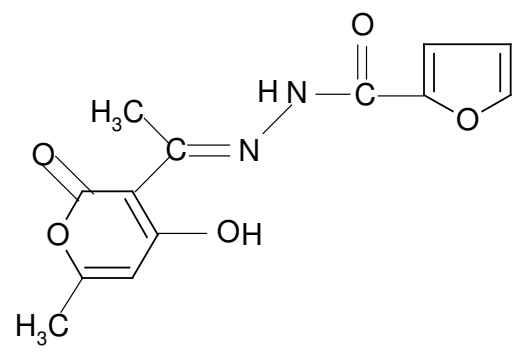

HMPFCH

The ${ }^{1} \mathrm{H}$ NMR spectrum of $\mathrm{HMCFCH}$ exhibits the following signals in $\mathrm{CDCl}_{3}: \delta 2.2(\mathrm{~s}, 3 \mathrm{H}$, $\left.\mathrm{C}_{4}-\mathrm{CH}_{3}\right), 2.6\left(\mathrm{~s}, 3 \mathrm{H}, \mathrm{CH}_{3}-\mathrm{C}=\mathrm{N}\right), 6.22\left(\mathrm{~s}, 1 \mathrm{H}, \mathrm{C}_{3}-\mathrm{H}\right), 7.58\left(\mathrm{~s}, 1 \mathrm{H}, \mathrm{C}_{5}-\mathrm{H}\right), 7.74\left(\mathrm{~s}, 1 \mathrm{H}, \mathrm{C}_{6}-\mathrm{H}\right), 8.66$ (s, 1H, CONH), 6.95 (m, 1H, H-2 furoyl), 6.27 (m, 1H, H-3 furoyl), 7.33 (m, 1H, H-4 furoyl), $12.13(\mathrm{~b}, 1 \mathrm{H}, \mathrm{OH})$.

The IR spectra of Mn(II), Fe(II), Co(II) and Ni(II) complexes of HMCFCH do not show the $v \mathrm{C}=\mathrm{O}$ (azide) IR frequency of the free ligand at $1670-1660 \mathrm{~cm}^{-1}$. It is also supported by the absence of $v \mathrm{NH}$ frequency around $3200-3300 \mathrm{~cm}^{-1}$ in metal complexes which supports its enolisation. This is further substantiated by the presence of new non ligand band in the spectra of the complexes around $1270-1240 \mathrm{~cm}^{-1}$, which is due to the enolisation of $\mathrm{vC}=\mathrm{O}$ (azide) and subsequent deprotonation of enolic $\mathrm{OH}$ and the participation of $\mathrm{vC}-\mathrm{O}$ enolic in complexation $[19,20]$. The IR data and the magnetic data of these complexes support the proposed enolic oxygen bridged dimeric structure. The $\mathrm{vC}=\mathrm{N}$ (azomethine) frequency of the free ligand undergoes a downward shift of $10-20 \mathrm{~cm}^{-1}$ in the spectra of the complexes, indicating the participation of $\mathrm{vC}=\mathrm{N}$ azomethine nitrogen in coordination [21]. The upward shift of $\mathrm{vC}-\mathrm{O}$ (phenolic) frequency in the spectra of complexes by $10-30 \mathrm{~cm}^{-1}$ indicates the participation of oxygen of phenolic group in complexation after deprotonation [22]. $\mathrm{Mn}$ (II), $\mathrm{Fe}$ (II) and $\mathrm{Co}$ (II) complexes of HMCFCH show an enolic oxygen bridged dimeric structure. This is further evidenced by the presence of new non ligand peaks at 1150 and $780 \mathrm{~cm}^{-1}$. The coordination of water molecules in the axial positions is supported by the presence of new medium intensity bands at $850-830 \mathrm{~cm}^{-1}$. In the spectrum of $\mathrm{Ni}(\mathrm{II})$ complex of $\mathrm{HMCFCH}$ a downward shift in 
$\mathrm{vC}=\mathrm{O}$ (lactone) to the extent of $25 \mathrm{~cm}^{-1}$ is observed. This supports the participation of lactone carbonyl in complexation. It leads to the proposal of a polymeric structure to the $\mathrm{Ni}$ (II) complex of $\mathrm{HMCFCH}$. In the spectra of $\mathrm{VO}$ (II) and $\mathrm{Cu}(\mathrm{II})$ complexes of $\mathrm{HMCFCH}$, the $\mathrm{vC}=\mathrm{O}$ (azide) around $1670-1660 \mathrm{~cm}^{-1}$ is intact and goes down by $10-15 \mathrm{~cm}^{-1}$ indicating its participation in complexation [23]. In the spectrum of $\mathrm{VO}$ (II) complex of $\mathrm{HMCFCH}$ the presence of non ligand bands around 990, 1160-1050 and $650-590 \mathrm{~cm}^{-1}$ are attributed to a sulfate bridged dimeric structure [24]. In the IR spectra of all the complexes $v \mathrm{C}=\mathrm{N}$ (azomethine) and $v \mathrm{C}-\mathrm{O}$ (phenolic) of free ligand undergo downward shift, proving the participation of nitrogen of $\mathrm{vC}=\mathrm{N}$ (azomethine) and oxygen of $\mathrm{vC}-\mathrm{O}$ (phenolic) in complexation. The IR spectrum $\mathrm{Cu}$ (II) complex of $\mathrm{HMCFCH}$ shows an absorption band at $320 \mathrm{~cm}^{-1}$ which is due $\mathrm{vCu}-\mathrm{Cl}$ [18]. This shows the participation of $\mathrm{Cl}^{-}$in complexation. The downward shift of $\mathrm{vC}=\mathrm{O}$ (lactone) supports the participation of oxygen of $\mathrm{vC}=\mathrm{O}$ (lactone) in coordination. The $\mathrm{Ni}$ (II) complex of HMCFCH exhibits a polymeric square planar geometry and the $\mathrm{Cu}$ (II) complex of $\mathrm{HMCFCH}$ shows a polymeric octahedral geometry. On the whole the $\mathrm{Mn}(\mathrm{II}), \mathrm{Fe}(\mathrm{II}), \mathrm{Co}(\mathrm{II})$ and $\mathrm{VO}$ (II) complexes of HMCFCH show a dimeric structure whereas the $\mathrm{Cu}(\mathrm{II})$ and $\mathrm{Ni}(\mathrm{II})$ complexes of the above ligand show a polymeric disposition [25].

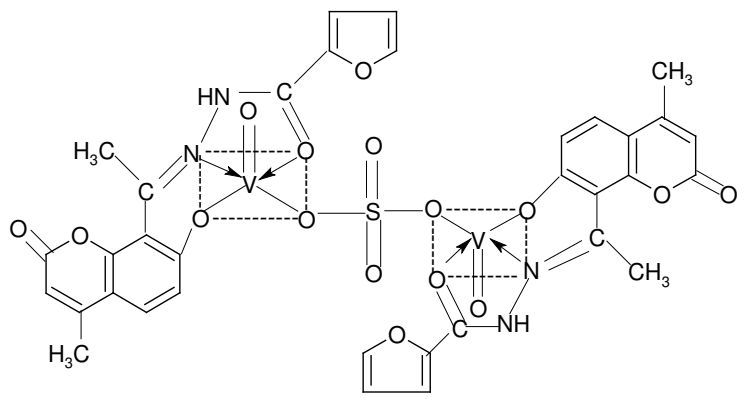

VO(II) complex of HMCFCH

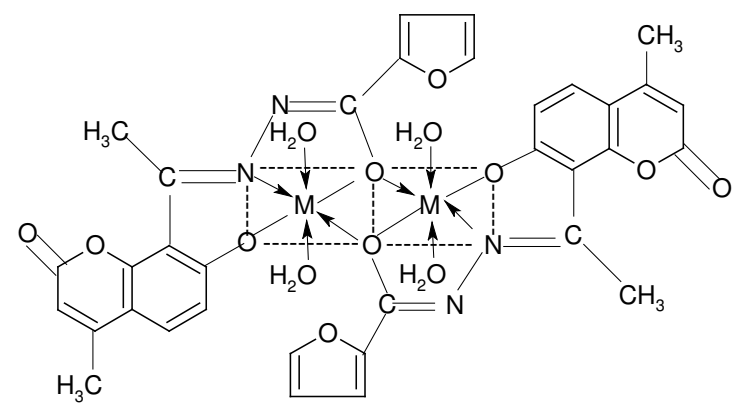

Complexes of $\mathrm{HMCFCH}$, where $\mathrm{M}=\mathrm{Mn}$ (II), $\mathrm{Fe}(\mathrm{II})$ and $\mathrm{Co}(\mathrm{II})$ 


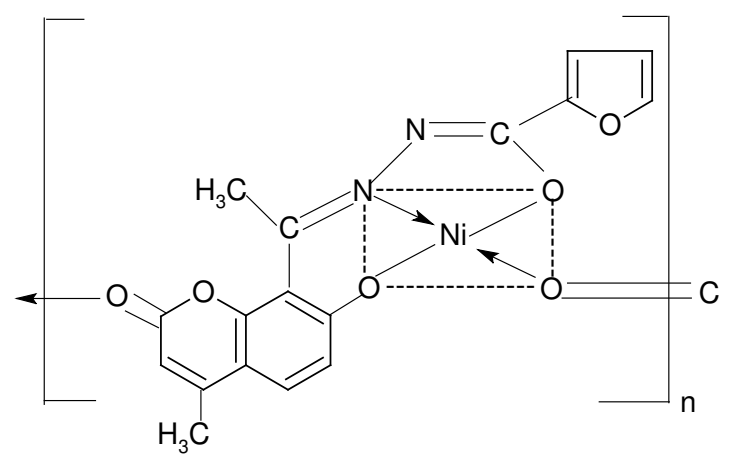

$\mathrm{Ni}(\mathrm{II})$ complex of $\mathrm{HMCFCH}$

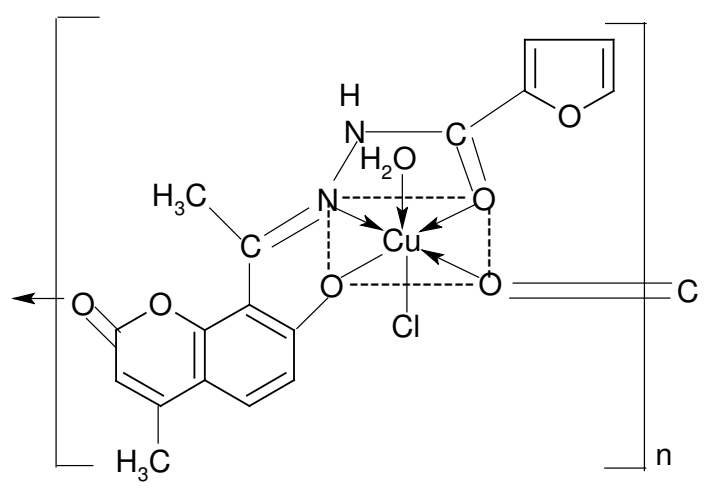

$\mathrm{Cu}$ (II) complex OF HMCFCH

The IR spectra of all the complexes of HMPFCH show a downward shift of $20 \mathrm{~cm}^{-1}$ in $\mathrm{vC}=\mathrm{N}$ (azomethine) indicating the participation of nitrogen of $\mathrm{vC}=\mathrm{N}$ (azomethine) in complexation. The upward shift of $\mathrm{VC}-\mathrm{O}$ (phenolic) at $1450-1500 \mathrm{~cm}^{-1}$ in the spectra of complexes indicate the participation of phenolic oxygen in coordination [18]. In the spectra of $\mathrm{Ni}$ (II), $\mathrm{Fe}$ (II) and $\mathrm{Co}$ (II) complexes of $\mathrm{HMPFCH}$, the $\mathrm{vC}=\mathrm{O}$ (azide ) at $1670-1660 \mathrm{~cm}^{-1}$ is absent and the $v \mathrm{NH}$ around $3200-3300 \mathrm{~cm}^{-1}$ is also absent, indicating the enolisation of $\mathrm{vC}=\mathrm{O}$ (azide) [21]. This is supported by a non ligand band due to $v \mathrm{C}-\mathrm{O}$ (enolic) at $1270-1240 \mathrm{~cm}^{-1}$. In view of the above evidences enolic oxygen bridged dimeric square planar geometry is proposed for $\mathrm{Ni}$ (II) complex. With two water molecules in the axial position, a dimeric octahedral structure is proposed for $\mathrm{Fe}$ (II) and $\mathrm{Co}$ (II) complexes of $\mathrm{HMPFCH}$. The presence of water molecules is supported by non-ligand bands at $830-850 \mathrm{~cm}^{-1}$. The IR spectra of VO(II) complex of HMPFCH shows non-ligand bands around 1050-1160 $\mathrm{cm}^{-1}$ and $510-650 \mathrm{~cm}^{-1}$ which are due to sulfate bridged square pyramidal geometry. In the spectra of $\mathrm{Cu}(\mathrm{II})$, $\mathrm{VO}$ (II), and $\mathrm{Mn}$ (II) complexes of $\mathrm{HMPFCH}$ the $\mathrm{vC}=\mathrm{O}$ (azide) at $1670-1660 \mathrm{~cm}^{-1}$ is intact and goes down by $15-20 \mathrm{~cm}^{-1}$ indicating its participation in complexation [25]. The presence of $v \mathrm{NH}$ around $3200-3300 \mathrm{~cm}^{-1}$ in the spectra of these complexes indicates the keto form of the azide moiety. This supports the nonenolisation of $\mathrm{vC}=\mathrm{O}$ (azide). The spectra of $\mathrm{Cu}$ (II) and $\mathrm{Mn}$ (II) complexes of $\mathrm{HMPFCH}$ exhibit 
an octahedral geometry with the participation of the nitrogen of azomethine, oxygen of $\mathrm{vC}=\mathrm{O}$ (azide) and oxygen of $\mathrm{vC}-\mathrm{O}$ (phenolic) in coordination with a 1:2 metal ligand ratio [21]. The spectrum of $\mathrm{VO}$ (II) complex suggests a sulfate bridged dimeric square pyramidal geometry.

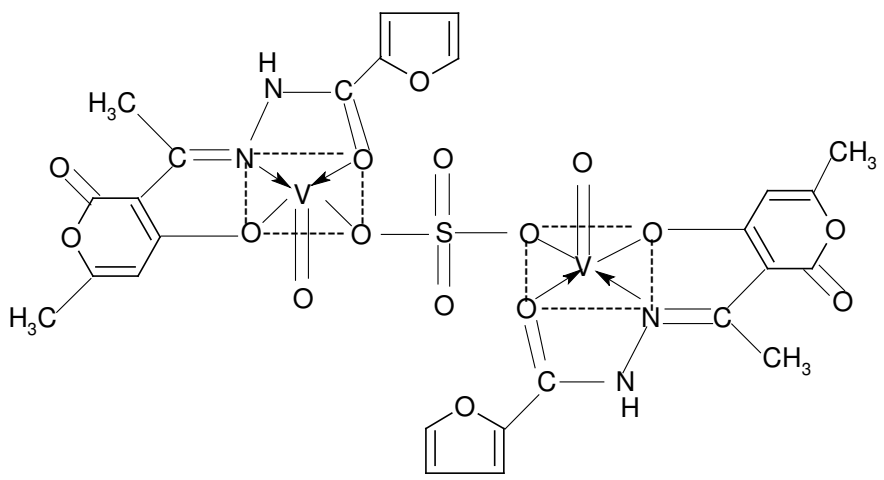

VO(II) complex of HMPFCH

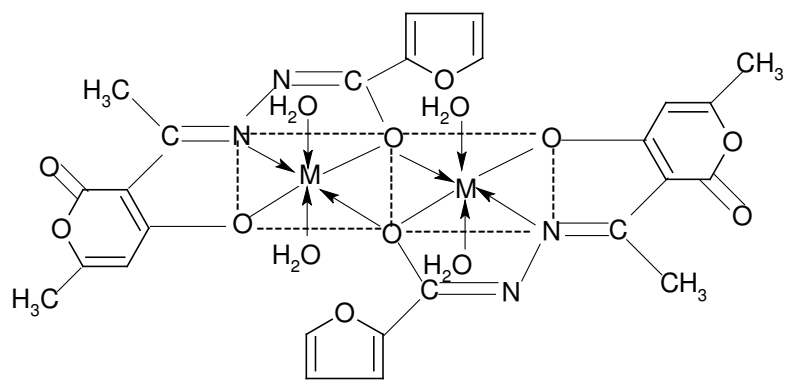

Complexes of $\mathrm{HMPFCH}$, where $\mathrm{M}=\mathrm{Fe}(\mathrm{II})$ and $\mathrm{Co}(\mathrm{II})$

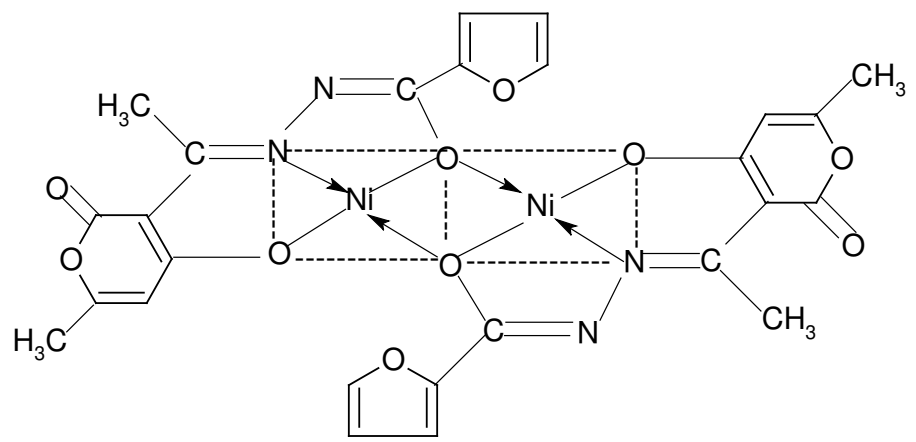

$\mathrm{Ni}(\mathrm{II}) \mathrm{cmplex}$ of $\mathrm{HMPFCH}$

Bull. Chem. Soc. Ethiop. 2007, 21(1) 




Complexes of $\mathrm{HMPFCH}$, where $\mathrm{M}=\mathrm{Mn}(\mathrm{II})$ and $\mathrm{Cu}(\mathrm{II})$

Thermogravimetric analyses of metal complexes of $\mathrm{HMCFCH}$ ascertain the presence of coordinated water. In case of $\mathrm{Mn}$ (II), $\mathrm{Co}$ (II) and $\mathrm{Fe}(\mathrm{II})$ complexes, the weight loss is found to be two moles of coordinated water per mole of the complex. The weight loss occurs at $140{ }^{\circ} \mathrm{C}$ in a single step. In case of $\mathrm{Cu}$ (II) complex of $\mathrm{HMCFCH}$ the weight loss has been found to be one mole of coordinated water per mole of the complex. Weight loss occurs at $150{ }^{\circ} \mathrm{C}$ [25]. In case of $\mathrm{Fe}(\mathrm{II})$ and $\mathrm{Co}$ (II) complexes of $\mathrm{HMPFCH}$, the weight loss has been two moles of coordinated water per mole of the complex and it occurs at $140{ }^{\circ} \mathrm{C}$. The magnetic moments of $\mathrm{VO}$ (II) complexes of HMPFCH and HMCFCH are 1.89 and 1.98 B.M., respectively. They are in good agreement with the sulfate bridged square pyramidal geometry. $\mathrm{Fe}(\mathrm{II})$ and $\mathrm{Co}$ (II) complexes of HMPFCH and HMCFCH show magnetic moments which are little less than the normally expected value. It indicates their dimeric nature. The magnetic moments are observed at 3.63, 3.72 B.M. for Co(II) complexes and 4.63 and 4.70 B.M. for Fe(II) complexes. Mn(II) complex of HMCFCH also exhibit subnormal magnetic moment value at 5.5 B.M., which is due to its dimeric octahedral structure. The lower values can be interpreted to the metal-metal bonding. The Mn(II) complex of HMPFCH possess a spin only magnetic moment value of 5.90 B.M. It is in agreement with the octahedral geometry. The Ni(II) complex of HMPFCH and HMCFCH show diamagnetism, which is due to their square planar disposition. Red color of complexes supports their square planar disposition. The $\mathrm{Cu}$ (II) complexes of both HMCFCH and HMPFCH show a normal magnetic moment value of 2.01 B.M and 1.98 B.M., which are in accordance with their distorted octahedral arrangement [27].

The electronic spectrum of VO(II) complex of HMCFCH shows three absorption bands at 12000, 19050 and $24300 \mathrm{~cm}^{-1}$, which are assigned to ${ }^{2} \mathrm{~B}_{2} \rightarrow{ }^{2} \mathrm{E} ;{ }^{2} \mathrm{~B}_{2} \rightarrow{ }^{2} \mathrm{~B}_{1}$ and ${ }^{2} \mathrm{~B}_{2} \rightarrow{ }^{2} \mathrm{~A}_{1}$ transitions. These are in accordance with the proposed square pyramidal geometry [30]. The electronic spectrum of VO(II) HMPFCH complex shows absorption bands at 12500, 17700 and $27397 \mathrm{~cm}^{-1}$ which are assignable to ${ }^{2} \mathrm{~B}_{2} \rightarrow{ }^{2} \mathrm{E} ;{ }^{2} \mathrm{~B}_{2} \rightarrow{ }^{2} \mathrm{~B}_{1}$ and ${ }^{2} \mathrm{~B}_{2} \rightarrow{ }^{2} \mathrm{~A}_{1}$ transitions, respectively, in a square pyramidal geometry. The $\mathrm{Mn}(\mathrm{II})$ complex of $\mathrm{HMCFCH}$ and $\mathrm{HMPFCH}$ exhibit three weak transitions each at $9091,15385,26316 \mathrm{~cm}^{-1}$ and 8300,16000 and $24500 \mathrm{~cm}^{-}$ ${ }^{1}$. These are assigned to ${ }^{6} \mathrm{~A}_{1 \mathrm{~g}} \rightarrow{ }^{4} \mathrm{E}_{\mathrm{g}}(\mathrm{D}),{ }^{6} \mathrm{~A}_{1 \mathrm{~g}} \rightarrow{ }^{4} \mathrm{~T}_{1 \mathrm{~g}}(\mathrm{P})$ and ${ }^{6} \mathrm{~A}_{1 \mathrm{~g}} \rightarrow{ }^{4} \mathrm{~T}_{2 \mathrm{~g}}(\mathrm{D})$, respectively. The 
$\mathrm{Fe}$ (II) complexes of HMCFCH and HMPFCH exhibit absorptions at 10500 and $11300 \mathrm{~cm}^{-1}$, respectively, which are assigned to a ${ }^{5} \mathrm{~T}_{2 \mathrm{~g}} \rightarrow{ }^{5} \mathrm{E}_{\mathrm{g}}$ transition and these are in accordance with the octahedral geometry [29]. The other transitions at 24510 and $29412 \mathrm{~cm}^{-1}$ are charge transfer transitions. The electronic spectra of Co(II) complexes of $\mathrm{HMCFCH}$ and $\mathrm{HMPFCH}$, respectively, show absorption bands at 9174,15723 and $9132,17600 \mathrm{~cm}^{-1}$. These are interpreted to ${ }^{4} \mathrm{~T}_{1 \mathrm{~g}}(\mathrm{~F}) \rightarrow{ }^{4} \mathrm{~T}_{2 \mathrm{~g}}(\mathrm{~F})$ and ${ }^{4} \mathrm{~T}_{1 \mathrm{~g}}(\mathrm{~F}) \rightarrow{ }^{4} \mathrm{~T}_{1 \mathrm{~g}}(\mathrm{P})$ transitions, respectively [30]. These transitions reveal an octahedral geometry around the $\mathrm{Co}$ (II) metal ion. The bands at 23000 and $23148 \mathrm{~cm}^{-1}$ are due to charge transfer transitions. The electronic spectrum of Ni(II) complexes of HMCFCH and HMPFCH shows two absorption bands each at 20000, 23148, and 19608, $24510 \mathrm{~cm}^{-1}$ which are interpreted to ${ }^{1} \mathrm{~A}_{1 \mathrm{~g}} \rightarrow{ }^{1} \mathrm{~A}_{2 \mathrm{~g}}$ and ${ }^{1} \mathrm{~A}_{1 \mathrm{~g}} \rightarrow{ }^{1} \mathrm{~B}_{1 \mathrm{~g}}$ transitions, respectively [31]. The transitions comply with the proposed square planar stereochemistry. The electronic spectra of $\mathrm{Cu}(\mathrm{II})$ complex of HMCFCH and HMPFCH shows intense broad bands at 15337 and $16027 \mathrm{~cm}^{-1}$. These are attributed to ${ }^{2} \mathrm{E}_{\mathrm{g}} \rightarrow{ }^{2} \mathrm{~T}_{2 \mathrm{~g}}$ transition in a distorted octahedral geometry [32]. The other bands at 22727 and $20921 \mathrm{~cm}^{-1}$ are assigned for charge transfer transitions.

ESR spectra of $\mathrm{Cu}$ (II) $\mathrm{HMCFCH}$ and $\mathrm{Cu}$ (II) $\mathrm{HMPFCH}$ were recorded at room temperature as powder. The spectra show $\mathrm{g}_{\mathrm{av}}$ values 2.09 and 2.092, respectively, which are consistent with their octahedral geometries.

\section{Anti microbial studies}

Determination of susceptibility of microorganisms to the ligands and complexes was carried out by paper disc plate method. The procedure is developed by Baver, Kirby, Sherins and Turk in 1966. In this method the sizes of the zones of inhibition is measured. Filter paper discs, petriplates and all the other apparatus used are sterilized before use. The solvents are dimethyl sulfoxide and methanol. 24 hour old bacterial cultures of Staphylococus aureus (gram $+\mathrm{ve}$ ), Pseudomonas aeruginosa (gram -ve) bacteria, spirit lamp, forceps, incubator and scale were used.

Procedure. $100 \mathrm{mg}$ of test compound is weighed and dissolved in $10 \mathrm{~mL}$ of DMSO-methanol medium. From this stock solution 1/10, 1/100, 1/200, 1/300, 1/400 and 1/500 dilutions were prepared in sterile test tubes with DMSO-methanol medium. 40 sterilized Whatman filter paper discs are dipped in each of the above dilute solutions. After soaking for 2 days, the filter paper discs were removed from the solutions and were dried. Nutrient agar plates were prepared. $1 \mathrm{~mL}$ of $S$. aureus culture was added in some plates and $1 \mathrm{~mL}$ of $P$. aeruginosa culture was added in some other plates. The culture broth is spread in the plates with a sterile spreader. The treated filter paper discs were placed in the inoculated plates using sterile forceps. Different concentrated discs were placed in different plates. They were incubated at $37{ }^{\circ} \mathrm{C}$ for $24 \mathrm{~h}$ in up right position. The plates were observed after $24 \mathrm{~h}$ and the zones of inhibition around the filter paper discs are noted down. The extent of inhibition was measured and the results are given in Table 3 and 4.

The observation of the Tables of biological activity of $S$. aureus and P. aeruginosa show that the metalation did not enhance the activity very much except in VO(II) complexes. This may be due to the presence of sulfur in the complex and may be partially due to the square pyramidal geometry. The ligands show more activity than the metal complexes against gram +ve and gram -ve bacteria. No activity has been shown by $\mathrm{Mn}$ (II) and $\mathrm{Cu}$ (II) complexes of HMPFCH. All the complexes of HMCFCH show some activity. The activity in general decreases with the increase in the dilution of the compounds. The activity against $S$. aureus is greater than the activity against $P$. aeruginosa. 
Table 3. Anti-microbial studies of the ligands and their metal complexes on Staphylococus aureus.

\begin{tabular}{|l|c|c|c|c|c|c|}
\hline Compound/concentration & $1 / 10$ & $1 / 100$ & $1 / 200$ & $1 / 300$ & $1 / 400$ & $1 / 500$ \\
\hline HMCFCH & +++++ & +++++ & +++ & +++ & ++ & + \\
VO(II)HMCFCH & ++++++ & +++++ & +++ & +++ & ++ & + \\
Mn(II)HMCFCH & +++ & +++ & +++ & ++ & + & - \\
Fe(II) HMCFCH & +++ & +++ & +++ & ++ & + & - \\
Co(II)HMCFCH & +++ & +++ & +++ & ++ & + & - \\
Ni(II)HMCFCH & ++++ & ++++ & +++ & +++ & ++ & + \\
$\mathrm{Cu}($ II) HMCFCH & ++ & ++ & ++ & + & - & - \\
\hline HMPFCH & ++++ & ++++ & ++++ & - & - & - \\
VO(II)HMPFCH & +++++ & +++++ & ++++ & +++ & ++ & + \\
Mn(II)HMPFCH & + & - & - & - & - & - \\
Fe(II)HMPFCH & ++ & +++ & ++ & ++ & - & - \\
Co(II)HMPFCH & +++ & +++ & ++ & ++ & - & - \\
Ni(II)HMPFCH & +++ & ++ & + & - & - & - \\
$\mathrm{Cu}$ (II)HMPFCH & + & - & - & - & - & - \\
\hline
\end{tabular}

Table 4. Anti microbial activities of ligands and their metal complexes on Pseudomonas aeruginosa.

\begin{tabular}{|l|c|c|c|c|c|c|}
\hline Compound/concentration & $1 / 10$ & $1 / 100$ & $1 / 200$ & $1 / 300$ & $1 / 400$ & $1 / 500$ \\
\hline $\mathrm{MCFCH}$ & ++++ & +++ & ++ & ++ & + & - \\
$\mathrm{VO}(\mathrm{II}) \mathrm{MCFCH}$ & ++++ & +++ & +++ & +++ & + & - \\
$\mathrm{Mn}(\mathrm{II}) \mathrm{HMCFCH}$ & ++ & ++ & ++ & + & + & - \\
$\mathrm{Fe}$ (II) HMCFCH & ++ & ++ & ++ & + & + & - \\
$\mathrm{Co}(\mathrm{II}) \mathrm{HMCFCH}$ & ++ & ++ & ++ & + & + & - \\
$\mathrm{Ni}(\mathrm{II}) \mathrm{HMCFCH}$ & ++++ & ++++ & ++ & + & + & + \\
$\mathrm{Cu}(\mathrm{II}) \mathrm{HMCFCH}$ & + & + & + & - & - & - \\
\hline $\mathrm{HMPFCH}$ & +++ & +++ & ++ & - & - & - \\
$\mathrm{VO}(\mathrm{II}) \mathrm{HMPFCH}$ & +++ & +++ & +++ & + & - & - \\
$\mathrm{Mn}(\mathrm{II}) \mathrm{HMPFCH}$ & - & - & - & - & - & - \\
$\mathrm{Fe}(\mathrm{II}) \mathrm{HMPFCH}$ & ++ & ++ & + & + & - & - \\
$\mathrm{Co}(\mathrm{II}) \mathrm{HMPFCH}$ & ++ & ++ & + & + & - & - \\
$\mathrm{Ni}(\mathrm{II}) \mathrm{HMPFCH}$ & +++ & ++ & + & - & - & - \\
$\mathrm{Cu}(\mathrm{II}) \mathrm{HMPFCH}$ & - & - & - & - & - & - \\
\hline
\end{tabular}

$+++++=$ Highest activity; $++++=$ very high activity; $+++=$ high activity $;++=$ moderate activity; $+=$ some activity; - = no activity.

\section{AKNOWLEDGEMENTS}

The authors are thankful to the Principal, P. G. College of Science, for providing facilities. The authors are also thankful to the Head, Department of Chemistry, Osmania University for recording the IR spectra and magnetic susceptibility measurements. The authors are also thankful to the Head, SAIF, IIT, Madras, Chennai, for recording the NMR spectra. The authors acknowledge Dr. Satya Prasad, Dr. Nagamani of Department of Biotechnology, P.G. College of Science, Saifabad for assisting in the screening of the compounds for anti microbial activities.

\section{REFERENCES}

1. Fontes, A.P.S.; Guerra, W.; Machado, F.C. Transition Met. Chem. 2004, 29, 382.

2. Sharma, V.K.; Srivastava, S. Synth. React. Inorg. Met. Org. Nano-Met. Chem. 2005, 35, 311. 
3. Iskander, M.F.; El-Sayed, L.; Salem, N.M.H.; Werner, R.; Haase, W. J. Coord. Chem. 2005, $58,125$.

4. Martsinko, E.E.; Seifullina, I.I.; Ya, Zub. V. Russ. J. Coord. Chem. 2005, 31, 795.

5. Goudar, T.R.; Maravalli, P.B. Indian J. Chem. 1998, 37A, 83.

6. Gudasi, K.B.; Goudar, T.R. Pol. J. Chem. 1999, 73, 385.

7. Yan, W.; Zheng, Y.Y.; Bao, D. Synth. React. Inorg. Met. Org. Nano-Met. Chem. 2005, 35, 237.

8. Rehman, S.U.; Mazhar, M.; Amin, B.; Sadiq, A.; Xuequing, S.; George, E.; Khalid, M.K. Synth. React. Inorg. Met. Org. Nano-Met. Chem. 2004, 34, 1379.

9. Yan, W.; Zheng-yin, Y.; Bao-dui, W. Transition Met. Chem. 2005, 30, 879.

10. Deepa, K.; Aravindakshan, K.K. Synth. React. Inorg. Met. Org . Nano-Met. Chem. 2005, 35, 409.

11. Chang, T.Y.; Ranford, J.D.; Jagdese, J.V. Synth. React. Inorg. Met. Org., Nano-Met. Chem. 2005, 35, 71 .

12. Michael, D.; Malachy, Mc.C.; Dennis, O.; Rachel, K.; Denise, E.; Carol, D. J. Inorg. Biochem. 2004, 98, 1023.

13. Salem, M.H.N. Synth. React. Inorg. Met. Org., Nano-Met. Chem. 2005, 35, 369.

14. Venkateswar Rao, P.; Venkata Narasaiah, A. Indian J. Chem. 2003, 42A, 1896.

15. Venkateswar Rao, P.; Aswini, K.; Fatima, K. Asian J. Chem. 2006, 18, 469.

16. Venkateswar Rao, P.; Venkata Narasaiah, A.; Ashwini, K. Bull. Pure. Appl. Sc. 2002, 21C, 91.

17. Nakamoto. K. Infrared and Raman Spectra of Inorganic and Coordination Compounds, Part B, 5th ed., John Wiley: New York; 1997; p 159.

18. Mamatha, K.; Rupini, B.; Srihari. S. J. Indian Chem. Soc. 2004, 81, 950.

19. Yang, Z.; Wen-Long, L.; Jing, L.; Chim, L.N.; Yuan-Gen, Y. J. Coord. Chem. 2005, 57, 381 .

20. Sharma, R.; Sharma, R.; Bala, N.; Quiros, M.; Sales, J.M. J. Coord. Chem. 2003, 56, 1581.

21. Bellamy, L.J. The Infrared Spectra of Complex Molecules, Vol. II, 2nd ed., Chapman and Hall: New York; 1980.

22. Adeniyi, A.A.; Patel, K.S. Synth. React. Inorg. Met. Org. Nano-Met. Chem. 1996, 26, 439.

23. Xiao -Min, Z.; Xiao-zeng, Y.; Polyhedron 1997, 15, 1793.

24. Syamal, A.; Gupta, B.K. Indian J. Chem. 1995, 34A, 495.

25. Singh, B.; Singh, U.R. Transition Met. Chem. 1995, 20, 100.

26. Ballhausen, C.J. Introduction to Ligand Field Theory, McGraw Hill: New York; 1962.

27. Lever, A.B.P. Inorganic Electronic Spectroscopy, Elsevier: Amsterdam; 1968.

28. Singh, N.K.; Kushawaha, S.K. Indian J. Chem. 2004, 43A, 1454.

29. Mane, P.S.; Shirodkar, S.G.; Chondhekar, T.K. J. Indian Chem. Soc. 2002, 79, 376.

30. Joshua, C.P.; George, A; Alaudeen, M. J. Indian Chem. Soc. 2004, 81, 357.

31. Bhasin, C.P.; Mehrotra, R.C. J. Indian Chem. Soc. 2002, 79, 336.

32. Mukherjee, G.N.; Chakraborty, P.K. J. Indian Chem. Soc. 2002, 79, 137. 